\title{
Three Dimensional Turbulent Fluid Flow and Heat Transfer Mathematical Model for the Analysis of a Continuous Slab Caster
}

\author{
M. R. R. I. SHAMSI and S. K. AJMANI
}

Steelmaking and Casting Group, Research and Development Department, Tata Steel, Jamshedpur-831 001, India. E-mail: mrrishamsi@yahoo.com

(Received on October 19, 2006; accepted on January 5, 2007)

Continuous casting of slab caster of Tata Steel has been simulated using a three dimensional mathematical model based on considerations of fluid flow, heat transfer and solidification for better understanding of the process. Liquid metal comes in the mould by bifurcated nozzle. The principal model equations are momentum and heat balances. In various zones, different standard boundary conditions have been used. In the mould region, Savage and Prichard expression for heat flux has been used. In the spray cooling zone, heat transfer coefficient for surface cooling of the slab has been calculated by knowing the water flow rate and nozzle configuration of plant. The turbulence in the molten metal has been modelled by the Realizable $k-\varepsilon$ model. CFD software (Fluent) has been used for the solution of equations to predict the velocities in the molten pool of the slab, temperature of the entire volume of the slab, heat transfer coefficient in the mould region, heat flux in the spray and radiation region and shell thickness. The variables studied are different casting speed.

KEY WORDS: slab caster; turbulence; solidification; shell profile; CFD; radiation cooling; spray cooling; heat flux; heat transfer coefficient; mathematical modelling; steel casting; realizable k-epsilon model.

\section{Introduction}

The schematic diagram of continuous casting is shown in Fig. 1. A detailed introduction of slab continuous casting plant of Tata Steel is available in literature. ${ }^{1)}$ In brief, molten metal comes from the tundish to mould through submerged entry nozzle (SEN). Figure 2 shows the schematic diagram of SEN. As molten metal comes in contact with water cooled copper mould wall, a thin skin of so-

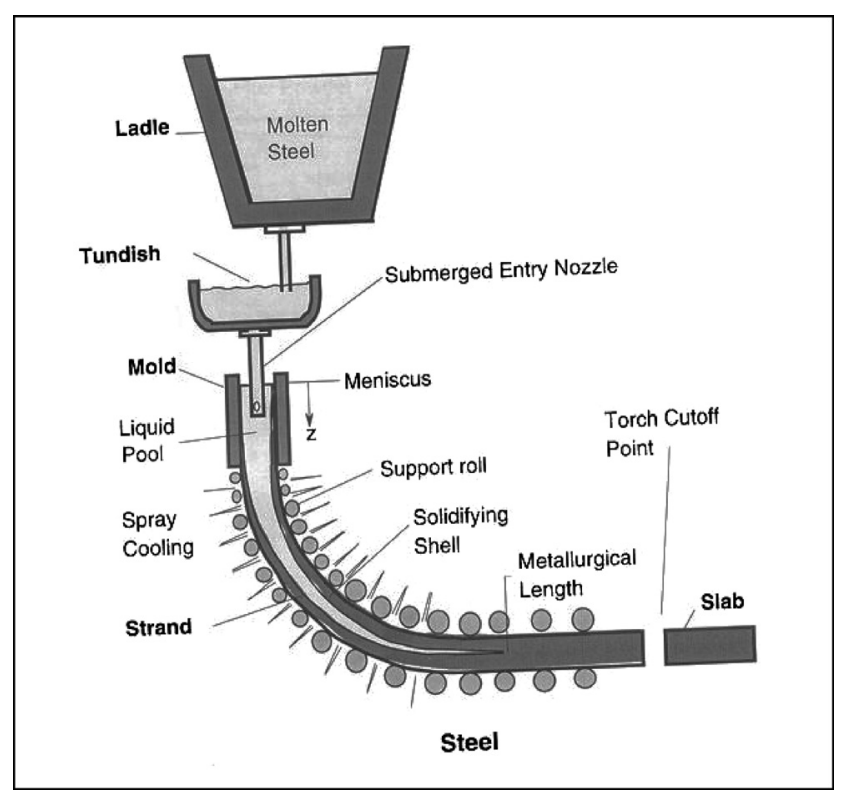

Fig. 1. Schematic diagram of continuous slab casting processes. lidified metal (Shell) forms, which grow its thickness during sojourn in the mould. During casting, mould is given a reciprocating motion in the vertical direction to reduce the risk of breakouts caused by rupture of the skin. Mould length should be optimum to satisfy the criteria of minimum length to minimize the friction between the mould inner wall and strand surface, and maximum length to maximize the shell thickness to withstand the liquid metal pressure. In the spray cooling zone, the cooling should be such that minimum thermal stress should be generated and

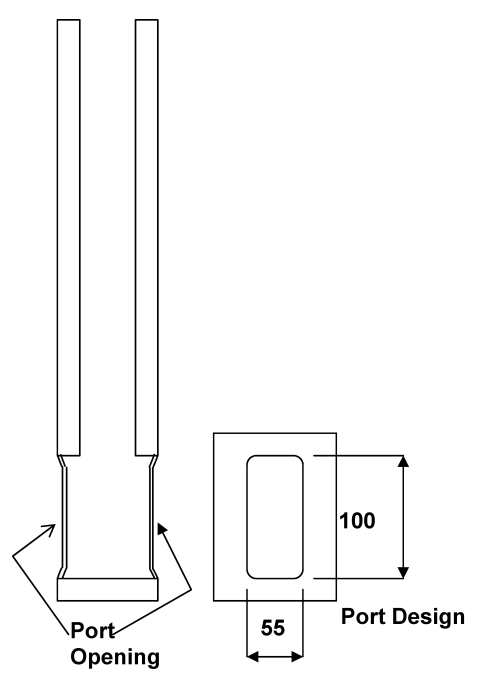

All dimensions are in $\mathbf{m m}$

Fig. 2. Schematic diagram of submerged entry nozzle (SEN). 
Table 1. Data of continuous casting used in the present computations.

\begin{tabular}{|c|c|}
\hline Parameters & Tata Steel, Slab Caster A \\
\hline Section Size $(\mathrm{m} \times \mathrm{m})$ & $\begin{array}{cc}1.5 \times 0.21 \\
(\mathrm{~W}) & (\mathrm{T})\end{array}$ \\
\hline SEN Diameter (m) & 0.075 \\
\hline SEN Wall Thickness (m) & 0.025 \\
\hline Depth of Submergence of nozzle (m) & 0.12 \\
\hline Mould Length (m) & 0.83 \\
\hline Spray Zone Length (m) & \\
\hline Zone 0 (N\&S) & 0.6 \\
\hline Spray Ring (Zone 0 ) & $0.24(1.07)$ \\
\hline $1 \mathrm{~A}$ & $1.12(2.19)$ \\
\hline 1B & $1.46(3.65)$ \\
\hline Zone 2 & $3.242(6.892)$ \\
\hline Zone 3 & $3.199(10.091)$ \\
\hline Zone 4 & $3.393(13.484)$ \\
\hline Zone 5 & $2.75(16.234)$ \\
\hline Length at Cut (m) & 31.0 \\
\hline Casting Speed (m/min) & $0.6-1.6$ \\
\hline Steel Carbon (\%) & 0.1 \\
\hline
\end{tabular}

austenite-ferrite phase transformation, which is accompanied by a sizeable volume change should not occur. To meet the above criteria, after certain length of spray cooling, the strand is allowed to be radiant cooled. The dimensions of the caster are given in Table 1. The spray zone length has been sub divided into six regions for flexibility of cooling. The first is spray ring region (Zone 0) just after the mould and having only water flow. In the narrow face of the slab, the spray ring region (Zone $0 \mathrm{N \& S}$ ) is also having only water flow. After this region, there is no forced cooling on the narrow face. After spray ring region other spray zones are named as $1 \mathrm{~A}, 1 \mathrm{~B}$, Zone 2, Zone 3, Zone 4 and Zone 5 as mentioned in Table 1.

Slab cast should be free from surfaces and internal cracks. For a given composition of steel, solidification in the slab casting will depend on fluid flow and heat transfer in different zones. In the mould region, the total heat transfer can be easily obtained by knowing difference of temperature between the inlet and the outlet of water passing through mould cooling jacket and its flow rate. Theoretically, it is difficult to get the heat transfer along the mould length because of air gap formation between mould and slab, resistance of heat flow due to shell formation, mould plate, water-copper plate, thermal contraction of slab and mould plate, bulging due to liquid height pressure. ${ }^{2-6)}$ Singh and Blazek ${ }^{7}$ have experimentally measured the heat transfer profile along the mould length by using a bench scale casting facility. Mould was stationary, unlike the actual caster. They have shown the effect of carbon content, casting speeds, pouring practice, mould flux additions and superheat on heat flux profile. Savage and Prichard ${ }^{8)}$ have given a equation for heat flux profile in the mould. Samrasekra and Brimacombe ${ }^{5)}$ have calculated the heat flux profile in the mould for different taper by measuring the temperature of the mould. They have also calculated the heat transfer for nucleate boiling in the channel. ${ }^{9}{ }^{9}$ Chatterjee et $a l .{ }^{10)}$ measured the plant mould wall temperature and developed a two dimensional heat transfer model for the mould wall to evaluate the primary cooling. Flow in the mould has been approximated by increasing the thermal conductivity of the liquid metal by many researchers. ${ }^{10-24)}$ Fluid flow in the molten pool of mould region has been simulated by two dimensional turbulent flow by some researchers. ${ }^{25,26)}$ Three dimensional turbulent fluid flow without solidification in the mould has been solved. ${ }^{27)}$ Huang et $a l{ }^{28)}$ have calculated the shell thickness in the mould based on three dimensional turbulent fluid flow and heat transfer for casting speed $1.0 \mathrm{~m} / \mathrm{min}$. Computational domain includes SEN. Thomas et al. ${ }^{29)}$ have discussed the argon bubble movement in the SEN and mould. Flint et al. ${ }^{30)}$ have calculated the impact pressure on narrow face of the slab and shell growth in the mould based on turbulent fluid flow through the SEN and heat transfer considerations. Computational domain is $2.0 \mathrm{~m}$ below meniscus. Sussman et al. ${ }^{31)}$ have solved the three-dimensional turbulent multi-phase fluid flow for behavior of the steel, argon and inclusion particles in both the water model and continuous caster. S. Qiu et $a l^{32)}$ have discussed the effect of thermal driven buoyancy on predicted flow and temperature obtained from a steady three-dimensional coupled fluid flow, heat transfer and macro-solidification model. Huang et al. ${ }^{33)}$ have developed a turbulent three-dimensional model to simulate the transient flow behavior in the mold. The flow velocity in the port has been given as boundary condition. Effect of argon flow on the liquid flow has been taken by increasing the turbulence. Seyedein et $a l^{34)}$ have calculated the shell thickness based on fluid flow and heat transfer considerations. The turbulent characteristics in the melt pool and mushy region are accounted for using the low-Reynolds number $k$-epsilon turbulence model by Launder and Sharma. ${ }^{35}$ Flint $^{36)}$ has developed a model based on turbulent flow, heat transfer and solidification. The casting speed is $1.3 \mathrm{~m} / \mathrm{min}$ and $8.0 \mathrm{~m}$ of the slab length has been modeled. The SEN stream is assumed to leave the ports at 30 degree downwards, and with a dispersion towards the broad faces of 15 degrees. Yuan et al. ${ }^{37,38)}$ have applied the LES model and shown that in the mould, flow is not symmetry. RamirezLopez et $a l .{ }^{39)}$ have shown that at the high casting speed there is no backflow in the SEN port area. By the water model meniscus shape has been measured and calculated. ${ }^{39,40)}$ Yang et $a l .{ }^{41)}$ have developed a mathematical model based on coupled flow, heat and solute transport. The casting speed is $1.2 \mathrm{~m} / \mathrm{min}$ and slab length modeled is $4.0 \mathrm{~m}$. The jet flow velocity at the port of the nozzle is determined through the mass conservation. K. Takatani et $a l^{42)}$ have developed three dimensional LES mathematical model to predict the meniscus shape with argon flow. The model has been validated by water model and by the low melting point alloy experiments. K. Takatani ${ }^{43}$ ) has further developed his model and shown the effect of port angle, argon flow, electromagnetic brake and electromagnetic stirrer on the meniscus behavior. In the spray cooling zone, variables are nozzle type, water pressure, nozzle to nozzle distance, nozzle to strand surface length and strand surface area cooled by water spray. Spray cooling on the strand involves boiling and formation of a steam layer on top of 
steel surface. Fundamental work for water spray by nozzle on hot plate has been published. ${ }^{44,45)}$ In the mist cooling, the compressed air is providing the kinetic energy necessary for penetration of the droplets through this steam layer. Thus in the mist cooling the strand surface heat transfer coefficient is high and there is uniformity of cooling. ${ }^{46)}$ Due to difficulty in measuring the heat transfer coefficient data of the plant, variation of its value between $100-2670 \mathrm{~W} \mathrm{~m}^{-2} \mathrm{~K}^{-1}$ has been taken in different studies. ${ }^{9,11,13,15,17,21,28)}$ For the given grade of steel, low ductility region can be found by Gleeble test. ${ }^{47)}$ In order to get insight of Tata Steel slab caster, a three dimensional mathematical model, taking into account turbulent fluid flow and heat transfer has been developed.

\section{Mathematical Model}

\subsection{Assumptions in the Model}

Due to complexity of the problem, the following simplified assumptions have been incorporated in the present mathematical model.

1. Steady state.

2. The cast section is of fixed dimension throughout the process and vertical.

3. Solidification is under equilibrium condition.

4. Transport of complex geometry inclusions through the liquid has been ignored. Entrapment of the inclusion on nozzle walls, gas bubbles, solidifying steel shell and the top surface has not been considered.

5. Thermodynamic and transport properties of steel are invariant.

6. Except for the latent heat release, heat effect associated with other phase transformation reactions (e.g., delta-ferrite-austenite, austenite-pearlite etc.) have been neglected.

7. Effect of segregation, mould oscillation, bending of strand etc. have been ignored.

8. Due to symmetry of heat flow in the slab, only a quadrant of its section has been considered for the analysis.

9. Metal level fluctuation and effect of mould powder have been ignored.

10. Flow in the liquid pool was assumed to be induced primarily by the momentum of the liquid jet coming from port. Influence of natural convection, bulging, suction due to solidification shrinkage etc. on liquid steel flow were ignored.

11. Darcy's law is applied as flow resistance through mushy zone.

12. The argon flow in the mould has been ignored.

2.2. Governing Equations ${ }^{48-50)}$

(a) Continuity equation

$$
\frac{\partial}{\partial x_{j}}\left(\rho u_{j}\right)=0
$$

(b) Momentum equations

$$
\begin{aligned}
\frac{\partial}{\partial x_{j}}\left(\rho u_{j} u_{i}\right)= & \frac{\partial}{\partial x_{j}}\left(\mu_{\mathrm{e}}\left(\frac{\partial u_{i}}{\partial x_{j}}+\frac{\partial u_{j}}{\partial x_{i}}\right) u\right)-\frac{\partial p}{\partial x_{i}} \\
& -\frac{(1-\beta)^{2}}{\left(\beta^{3}+0.001\right)} A_{\text {mush }}\left(u_{i}-u_{\mathrm{s}}\right)+\rho \vec{g}
\end{aligned}
$$

$$
\mu_{\mathrm{e}}=\mu_{1}+\mu_{\mathrm{t}}
$$

(c) Realizable $\kappa-\varepsilon$ turbulent model equations

$$
\frac{\partial}{\partial x_{j}}\left(\rho k u_{j}\right)=\frac{\partial}{\partial x_{j}}\left[\left(\mu_{1}+\frac{\mu_{\mathrm{t}}}{\sigma_{k}}\right) \frac{\partial k}{\partial x_{j}}\right]+G_{k}-\rho \varepsilon . .
$$

and

$$
\begin{aligned}
\frac{\partial}{\partial x_{j}}\left(\rho \varepsilon u_{j}\right)= & \frac{\partial}{\partial x_{j}}\left[\left(\mu_{1}+\frac{\mu_{\mathrm{t}}}{\sigma_{\varepsilon}}\right) \frac{\partial \varepsilon}{\partial x_{j}}\right]+\rho C_{1} S \varepsilon \\
& -\rho C_{2} \frac{\varepsilon^{2}}{k+\sqrt{v \varepsilon}}
\end{aligned}
$$

Where

$$
\begin{aligned}
& G_{k}=\mu_{\mathrm{t}} \frac{\partial u_{j}}{\partial x_{i}}\left(\frac{\partial u_{j}}{\partial x_{i}}+\frac{\partial u_{i}}{\partial x_{j}}\right) \\
& C_{1}=\max \left[0.43, \frac{\eta}{\eta+5}\right], \quad \eta=S \frac{k}{\varepsilon}, \quad S=\sqrt{2 S_{i j} S_{i j}} \\
& \mu_{\mathrm{t}}=\rho C_{\mu} \frac{k^{2}}{\varepsilon} \\
& C_{\mu}=\frac{1}{A_{\mathrm{o}}+A_{\mathrm{s}} \frac{k U^{*}}{\varepsilon}}
\end{aligned}
$$

Where

$$
\begin{aligned}
& U^{*}=\sqrt{S_{i j} S_{i j}+\hat{\Omega}_{i j} \hat{\Omega}_{i j}} \\
& \hat{\Omega}_{i j}=\Omega_{i j}-2 \varepsilon_{i j k} \omega_{k} ; \quad \Omega_{i j}=\bar{\Omega}_{i j}-\varepsilon_{i j k} \omega_{k}
\end{aligned}
$$

Where $\overline{\Omega_{i j}}$ is the mean rate of rotation tensor viewed in a rotating reference frame with the angular velocity $\omega_{k}$.

The model constants $A_{o}$ and $A_{s}$ are given by

$$
A_{\mathrm{o}}=4.04, \quad A_{\mathrm{s}}=\sqrt{6} \cos \phi
$$

Where

$$
\begin{gathered}
\phi=\frac{1}{3} \cos ^{-1}(\sqrt{6} W), \quad W=\frac{S_{i j} S_{j k} S_{k i}}{\hat{S}^{3}}, \quad \hat{S}=\sqrt{S_{i j} S_{i j}}, \\
S_{i j}=\frac{1}{2}\left(\frac{\partial u_{j}}{\partial x_{i}}+\frac{\partial u_{i}}{\partial x_{j}}\right)
\end{gathered}
$$

(d) Energy equations

$$
\begin{aligned}
& \frac{\partial}{\partial x_{i}}\left(\rho u_{i} H\right)=\frac{\partial}{\partial x_{i}}\left(\frac{k_{\mathrm{eff}}}{c_{\mathrm{p}}} \frac{\partial H}{\partial x_{i}}\right)-\frac{\partial\left(\rho \beta u_{i} \Delta H_{\mathrm{f}}\right)}{\partial x_{i}} \\
& -\frac{\partial\left[\rho(1-\beta)\left(u_{i}-u_{i_{\mathrm{s}}}\right) \Delta H_{\mathrm{f}}\right]}{\partial x_{i}} \\
& \Delta H=\beta \Delta H_{\mathrm{f}} . \\
& H=h+\Delta H \text {. } \\
& h=h_{\text {ref }}+\int_{\text {ref }}^{T} c_{\mathrm{p}} \partial T \\
& k_{\text {eff }}=k_{1}+\frac{c_{\mathrm{p}} \mu_{\mathrm{t}}}{P r_{\mathrm{t}}}
\end{aligned}
$$




$$
\begin{aligned}
& \beta=0 \text { if } T<T_{\text {solidus }} \\
& \beta=1 \text { if } T>T_{\text {liquidus }} \\
& \beta=\frac{T-T_{\text {solidus }}}{T_{\text {liquidus }}-T_{\text {solidus }}} \text { if } T_{\text {solidus }}<T<T_{\text {liquidus }}
\end{aligned}
$$

\subsection{Boundary Conditions}

Because of three dimensional geometry, it is difficult to show all the boundary conditions in pictorial form. Figure 3 shows the boundary conditions in the XY central plane.

Inlet: Molten metal comes in to the mould through submerged entry nozzle (SEN). The mass flow rate of the molten metal has been specified as inlet condition in the SEN. Two percent turbulent intensity has been assumed at the inlet. Temperature at the inlet has been taken to be the pouring temperature.

Free Surface: Zero shear stresses have been taken at the free surface. To account for the heat loss by radiation at the free surface, Stefan's Law has been used. Emissivity is taken to be 0.8 .

Solid Wall: Solid wall is formed by solidification of liquid metal and is called shell. No slip condition has been taken at the solid wall. Fine mesh near the wall is required to correctly predict the shell thickness. For the turbulence, enhanced wall treatment method is used. In the steady state, total heat transfer from the slab surfaces in the mould region is equal to heat carried by water passing through the mould jacket. This value has been calculated by measuring the water flow rate and increase of its temperature after passing through the mould jacket. By assuming heat flux in the mould does not vary along the width of the mould, Savage and Prichard ${ }^{8)}$ gave a relation for heat flux in the mould as follow

$$
q_{\mathrm{m}}=\left[2.67-0.33 \sqrt{\frac{y}{U}}\right] \times 10^{6} \mathrm{~W} \mathrm{~m}^{-2}
$$

This expression has been integrated on the slab surfaces, and total heat flux is calculated. The total heat transfer obtained from this calculation and from the slab caster mould is in the same range, hence this expression is used for the slab surface heat flux boundary condition in the mould region. Higher values of heat flux have been taken near the meniscus because of more cooling. ${ }^{34)}$ The solid wall moves with the casting speed in axial direction.

In the spray cooling zone, heat extracted from the surface of the caster is

$$
q_{\mathrm{s}}=h_{\mathrm{s}}\left(T_{\mathrm{s}}-T_{\mathrm{w}}\right)+\sigma \varepsilon_{\mathrm{s}}\left(T_{\mathrm{s}}^{4}-T_{\mathrm{a}}^{4}\right)
$$

To know $h_{\mathrm{s}}$, number of nozzles, nozzle to nozzle distance, nozzle to strand surface distance has been measured. From the water flow rate in each nozzle and characteristic of the nozzle, water flux at the strand surface has been calculated. For the water flow the spray heat transfer coefficient is given by ${ }^{51)}$

$$
h_{\mathrm{s}}=165.0 \mathrm{~W}^{0.75}
$$

$W$ is in $1 / \mathrm{m}^{2} \mathrm{~s}$.

For the mist cooling, the spray heat transfer coefficient is given by ${ }^{52,53)}$

$$
h_{\mathrm{s}}=350.0 \mathrm{~W}+130.0
$$

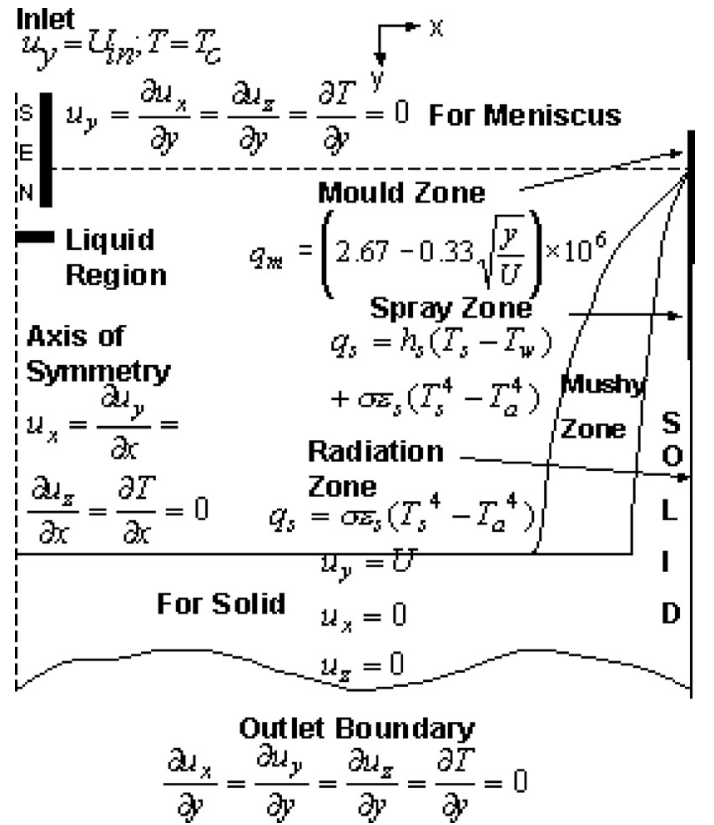

Fig. 3. Boundary conditions for XY central plane.

Table 2. Numerical values of heat transfer coefficient $\left(\mathrm{W} \mathrm{m}^{-2} \mathrm{~K}^{-1}\right)$ in the spray zones at different casting speed.

\begin{tabular}{|l|l|l|l|l|l|l|l|l|}
\hline $\begin{array}{l}\text { Casting } \\
\text { Speed } \\
(\mathrm{m} / \mathrm{min})\end{array}$ & $\begin{array}{l}\text { Zone 0 } \\
\text { N\&S }\end{array}$ & Zone 0 & $\begin{array}{l}\text { Zone } \\
1 \mathrm{~A}\end{array}$ & $\begin{array}{l}\text { Zone } \\
1 \mathrm{~B}\end{array}$ & Zone 2 & Zone 3 & Zone 4 & Zone 5 \\
\hline 1.6 & 780 & 580 & 580 & 531 & 222 & 193 & 179 & 179 \\
\hline 1.0 & 532 & 412 & 412 & 380 & 187 & 169 & 160 & 160 \\
\hline 0.6 & 392 & 300 & 300 & 281 & 164 & 150 & 148 & 148 \\
\hline
\end{tabular}

For the calculation of $h_{\mathrm{s}}$, it has been assumed that the slab surface temperature is always above Leidenfrost temperature $^{54)}$ in the spray zone. At high temperature, the cooling water forms a stable film on the slab surface which protects the surface from the direct contact with the coolant. When the temperature decreases the vapour layer collapses, the cooling increases instantly. The dividing temperature between these temperature area is termed as Leidenfrost temperature. Unfortunately, the Leidenfrost temperature for the nozzles and parameters used in continuous casting is somewhere between 1300 and $300^{\circ} \mathrm{C}$. For different casting speeds and different regions, spray heat transfer coefficient is given in Table 2.

In the radiation cooling zone below sprays, surface heat flux can be represented by the following expression

$$
q_{\mathrm{s}}=\sigma \varepsilon_{\mathrm{s}}\left(T_{\mathrm{s}}^{4}-T_{\mathrm{a}}^{4}\right)
$$

Outlet: At the outlet, zero normal gradient of all the variables are taken.

$Y-Z$ Symmetry Plane: $\quad u_{z}=\partial u_{y} / \partial z=\partial T / \partial z=0$.

\section{Solution Procedure}

Fluent CFD software has been used for computation. Gambit software has been used for mesh generation. The grid taken is nonuniform. Fine grid has been taken near the wall and in the region of steep velocity and temperature gradient. For the slab surface, mesh is fine near to meniscus. It has been assured that the ratio between the succes- 
sive mesh length should not exceed 1.5. Total cells are 0.51 millions. At the inlet, by connecting all the surface meshes, volume mesh is created. Control volume technique has been used for the solution. ${ }^{55)}$ Convection terms are discretized by second order upwind scheme and the second order central scheme is used for diffusive term. First the equations are solved to get the velocities and then energy equations are solved to get the temperature. Turbulent Prandtle number for Kinetic energy is equal to 1.0. Enthalpy-porosity technique has been used for solidification process. ${ }^{56)}$ In this technique, the melt interface is not tracked explicitly. Instead, a quantity called the liquid fraction, which indicates the fraction of the cell volume that is in liquid form, is associated with each cell in the domain. The liquid fraction is computed at each iteration, based on an enthalpy balance. The mushy zone is a region in which the liquid fraction lies between 0 and 1 . The mushy zone is modeled as a "pseudo" porous medium in which the porosity decreases from 1 to 0 as the material solidifies.

\section{Results and Discussion}

Thermodynamic and transport properties employed in the computation are shown in Table 3. Figure 4 shows the

Table 3. Numerical values of the variables used in the computations.

\begin{tabular}{|l|l|}
\hline Process Variables & Numerical Values \\
\hline Melt superheat $\left({ }^{\circ} \mathrm{C}\right)$ & 25.0 \\
Solidus temperature $\left({ }^{\circ} \mathrm{C}\right)$ & 1496.0 \\
Liquidus temperature $\left({ }^{\circ} \mathrm{C}\right)$ & 1529.0 \\
Density of steel $\left(\mathrm{Kg} \mathrm{m}^{-3}\right)$ & 7400.0 \\
Specific heat of steel $\left(\mathrm{J} \mathrm{Kg}^{-1}{ }^{\circ} \mathrm{C}^{-1}\right)$ & 682.0 \\
Thermal conductivity of steel $\left(\mathrm{W} \mathrm{m}^{-1}{ }^{\circ} \mathrm{C}^{-1}\right)$ & 34.6 \\
Viscosity of steel $\left(\mathrm{Kg} \mathrm{m}^{-1} \mathrm{~s}^{-1}\right)$ & 0.0062 \\
Latent heat of solidification $\left(\mathrm{J} \mathrm{Kg}^{-1}\right)$ & 271954 \\
Emissivity of steel & 0.8 \\
Energy Turbulent Prandtl number & 0.85 \\
\hline
\end{tabular}

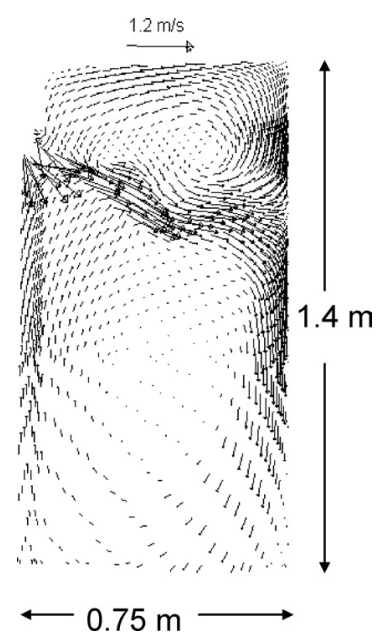

Fig. 4. Velocity vector plots of XY central plane at casting speed $1.6 \mathrm{~m} / \mathrm{min}$. velocity vectors at the center of the slab along the axial distance. Liquid metal jet is directed towards the narrow face. The velocities decreases along $x$ direction because of expansion of liquid jet. During it movements it drag the liquid metal and thus create two recirculatory zones. Upper recirculation is strong because the port is near to free surface. This recirculation transfers heat to mould flux for melting. It can be observed that even at the depth $1.4 \mathrm{~m}$ from the meniscus, the velocity is significant and recirculatory.

Figure 5 shows the temperature of the slab along the axial direction. In this figure, upper curve (center) is for the slab center temperature. This temperature decreases slowly till solidification. After that there is faster decrease of the temperature because of no latent heat release. The curve (width) which is just below the solid line is for slab middle wide side surface temperature as also shown in the figure. There is sharp decrease of temperature in the mould region. After the mould region, the temperature first increases in the spray ring cooling zone (zone 0), because the heat supplied from the central portion of the liquid is more than the heat removed from the surface by spray water. The reheat temperature is approximately $200^{\circ} \mathrm{C}$. This trend is continued to some distance in the zone $1 \mathrm{~A}$, because of same heat transfer coefficient. The surface of slab attains a peak temperature due to equilibrium between heat supplied from the central portion of the liquid and heat removed by water spray. Thereafter temperature decreases. The decrease of temperature is continued in zone 1B. In zone 2, the surface temperature increases, because of less value of heat transfer coefficient. The increase of temperature is approximately $100^{\circ} \mathrm{C}$. In the zone 3,4 and 5 the surface temperature reduces very less because of low cooling. After zone 5, there is slight increase of temperature, because the spray cooling is stopped and slab is allowed to be radiant cooled. The curve (thickness) which is solid line is for slab middle nar-
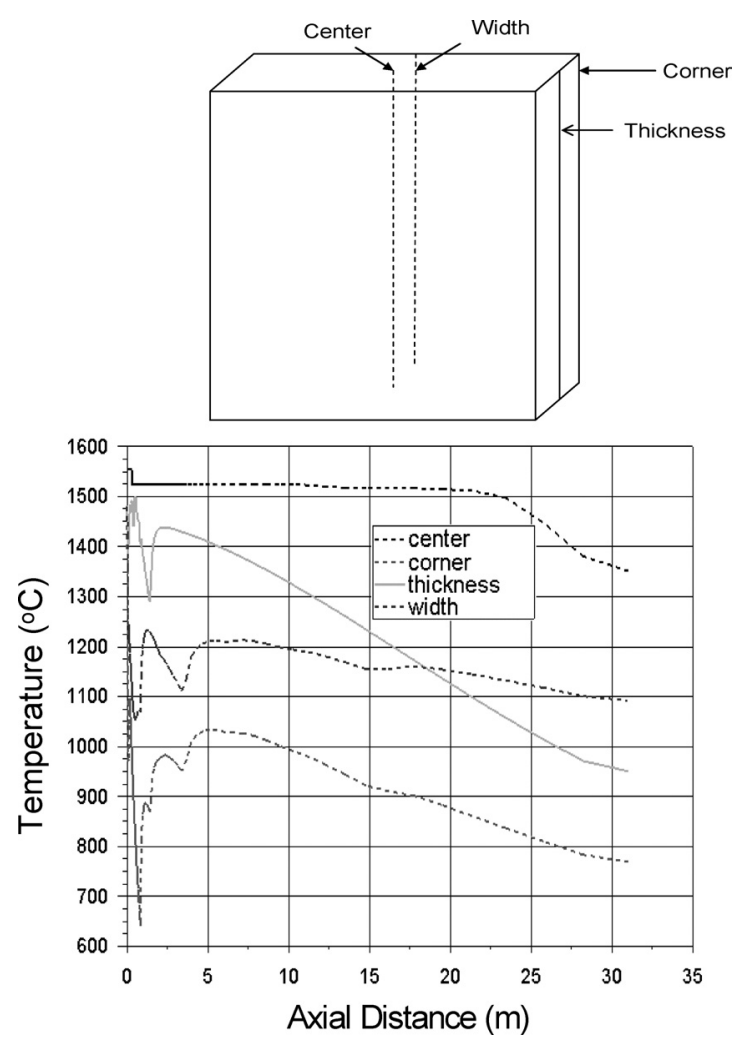

Fig. 5. Temperature profile for the casting speed $1.6 \mathrm{~m} / \mathrm{min}$. 
row side surface temperature. The width of the narrow side decides the thickness of the slab. Unlike the width curve, there is no sharp decreases of temperature in this surface. Because of superheated liquid jet impinging the surface, remelting of solidified shell takes place in the upper region of mould. The temperature decreases in the lower region of the mould. The decrease of temperature is continued in zone $0 \mathrm{~N} \& \mathrm{~S}$, because of high surface temperature the heat extraction from surface is more than heat supplied from the center. The surface temperature increases after this zone because the spray cooling is stopped. It attains a maximum temperature for the same reason as stated above and thereafter temperature decreases because of radiation cooling. The reheat temperature is approximately $150^{\circ} \mathrm{C}$. This temperature goes below the upper curve at around $12.0 \mathrm{~m}$, because there is thick shell at this point and thus there is not much heat flux from the center.

The measured temperature by radiation pyrometer at a distance $10 \mathrm{~m}$ from the meniscus at thickness direction is in the range of 950 to $1200^{\circ} \mathrm{C}$, which is below the predicted temperature. This may be attributed partly due to argon flow and partly due to measurement errors. The variation of temperature is because of scale, vapour and smoke formation. Work is in progress to minimize this variation. The corner temperature is less because of two dimensional cooling.

Salient features of the formulation are three dimensional model and more realistic representation of the turbulent fluid flow phenomena in the molten pool region and in the SEN. Unlike the previous work, where the velocities in the molten pool region are represented by enhanced thermal conductivity or two dimensional fluid flow, the flow in this formulation is taken to be three dimensional and turbulent. The Reynold number of the molten stream varies from 61000 to 150000.0 . With such a high Reynold number, flow will be turbulent. Realizable $k-\varepsilon$ model has been used to model the turbulence to avoid the singularity at low value of turbulence. It can be seen that in Eq. (5), denominator never vanishes even $k$ is zero, which is not the case with standard $k-\varepsilon$ model. Since molten metal is at high temperature and opaque, direct measurement is very difficult. To understand the fluid flow phenomena in the slab caster, simulation work with water has been carried out. This work is very useful in understanding the nature of flow in the molten pool. There are limitations with water simulation. It is difficult to simulate the growth of solidified shell and movement of the solidified shell.

One drawback of this formulation is not taking account the argon flow rate through the SEN. This effect will reduce the impinging velocity of the jet to the narrow face. In actual case, the shell thickness is expected more than the calculated one.

Though the caster has the curve shape, it has been assumed to be a vertical. This assumption may affect the gravity term in fluid flow. It also affects the surface area for heat transfer and boundary area for fluid flow. If the objective is to predict the inclusion float out, it is better to take the caster to be curve and computation is confined to mould region only. But due to fluid flow being more significant in the upper region of the mould, it is expected that the computationally obtained shell thickness and temperature profiles with curve caster and vertical caster will not differ much from each other.
In the upper region of the mould, the force convection is dominant than the natural convection. In the lower region, the velocity and temperature of liquid metal are low, thus natural convection will not affect the result much. To study the microstructure evolution, considering natural convection in the model will be useful. In this model, natural convection effect can be included easily. In comparison with spray cooling, the effect of natural convection cooling is negligible. In the absence of spray cooling, radiation cooling and natural convection cooling have been compared. The maximum effect is at the top of thickness direction, which is two percent of radiation cooling. Thus the effect of natural convection cooling is neglected.

The maximum allowable surface reheat will depend mostly on cast structure and steel composition. Steel which has a predominantly equiaxed structure, such as is obtained by casting at low superheat, can resist the formation of cracks even with large reheats of $200^{\circ} \mathrm{C}$. On the other hand, steel cast with a large columnar zone is very susceptible to cracking with much lower reheating. Steel with carbon contents between 0.17 and $0.24 \%$ or greater than $0.6 \%$ is more prone to cracking than other carbon grades. Also, steel with sulphur levels above $0.025 \%$, phosphorus contents above $0.03 \%$ or magnese concentrations in excess of $1.0 \%$ is reported to be more subject to cracking. If the common grades have a ductility to fracture of 0.2 to $0.3 \%$ and a thermal expansion coefficient of $0.2 \%$ per $100^{\circ} \mathrm{C}$, the maximum reheat should be about $100^{\circ} \mathrm{C}$. However, it may be wiser to adopt a safety factor and take $50^{\circ} \mathrm{C}$ as the maximum value. ${ }^{57,58)}$ By the calculation it has been found that the calculated surface reheat is above $50^{\circ} \mathrm{C}$ at lot of surfaces.

Figure 6 shows the shell thickness in the axial direction at symmetric planes at casting speed $1.6 \mathrm{~m} / \mathrm{min}$. The solid line (width) is for shell thickness growing at the central plane at the width and growing in thickness direction. Initially there is rapid growth of solidified shell because of high extraction of heat in the mould zone. Thereafter there is not much change of shell thickness up to certain distance because of reduce cooling. After that the shell thickness increases, but the rate of growth is less because heat has to flow from the center of the slab via thick shell. Near the end of solidification, all the molten metal is in mushy form, which solidify quickly to a shell. The complete solidification takes place at the axial distance $25.0 \mathrm{~m}$ from the meniscus. The dotted line (thickness) is for shell thickness growing at the central plane at the narrow side and growing par-

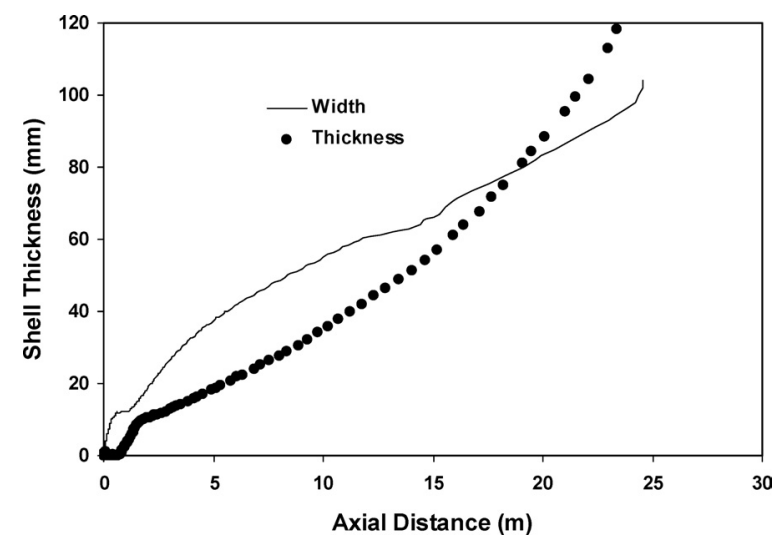

Fig. 6. Shell thickness along the axial direction at symmetric planes at casting speed $1.6 \mathrm{~m} / \mathrm{min}$. 


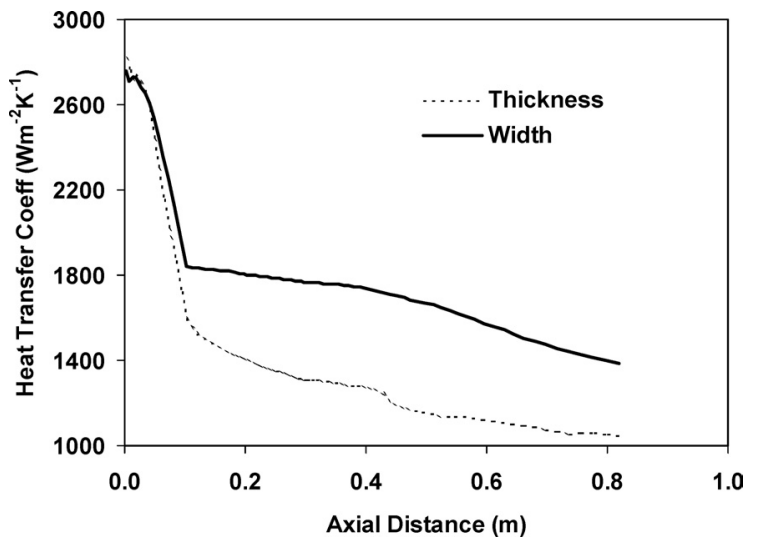

Fig. 7. Variation of slab surface heat transfer coefficient in the mould region along the axial distance at the center of the surfaces at casting speed $1.6 \mathrm{~m} / \mathrm{min}$.

allel to width. Initially shell thickness is less because of liquid jet impinging on the narrow face. Below the strong fluid flow zone, there is rapid growth of shell thickness. After cooling is stopped, there is decrease of growth rate of shell thickness. Due to combined effect of cooling from the narrow and wide faces, there is rapid growth rate of shell thickness at the end of solidification.

Figure 7 shows the computationally obtained slab surfaces heat transfer coefficient in the mould region along the axial distance at casting speed $1.6 \mathrm{~m} / \mathrm{min}$. The upper curve (width) is at the center of wide surface of slab. Its value is $2750.0 \mathrm{~W} \mathrm{~m}^{-2} \mathrm{~K}^{-1}$ at the meniscus. Because of rapid solidification near the free surface, its value decreases very fast up to $0.1 \mathrm{~m}$. After the axial distance $0.1 \mathrm{~m}$, the heat transfer coefficient decreases linearly. At the exit of the mould the heat transfer coefficient is $1400.0 \mathrm{~W} \mathrm{~m}^{-2} \mathrm{~K}^{-1}$. This low heat transfer coefficient is due to the air gap formation between the slab and the mould. After exit from the mould, the preliminary calculation shows that in the spray ring region the heat transfer coefficient is $580 \mathrm{~W} \mathrm{~m}^{-2} \mathrm{~K}^{-1}$. The sudden change in the heat transfer coefficient from mould to spray region may lead to stress generation, crack formation and abrupt change of microstructure in the slab. The lower curve (thickness) is for the center of narrow surface of slab. The value is lower than the upper curve because the heat flux is same in both the case, but slab temperature at this surface is high which gives lower heat transfer coefficient. The value at the exit of the mould at this surface is $1050 \mathrm{~W} \mathrm{~m}^{-2} \mathrm{~K}^{-1}$. In the spray ring zone (Zone $0 \mathrm{~N} \& \mathrm{~S}$ ), the spray heat transfer coefficient value is $780 \mathrm{~W} \mathrm{~m}^{-2} \mathrm{~K}^{-1}$. This sudden change of heat flux should be avoided for the same reason as discussed above.

Figure 8 shows the change of calculated heat flux along the axial distance at the center of the surfaces at casting speed $1.6 \mathrm{~m} / \mathrm{min}$. For the sake of comparison, the heat flux value of the mould also has been included. Figure clearly shows the abrupt change of heat flux. It is desirable to have the smooth change of heat flux for the same reason as discussed in the above figure.

Figure 9 shows the temperature profile along the axial direction for the casting speed $1.0 \mathrm{~m} / \mathrm{min}$. In this figure, upper curve (center) is for the slab center temperature. This temperature decreases slowly till solidification. After that there is faster decrease of the temperature. The curve (width) which is just below the solid line is for slab middle

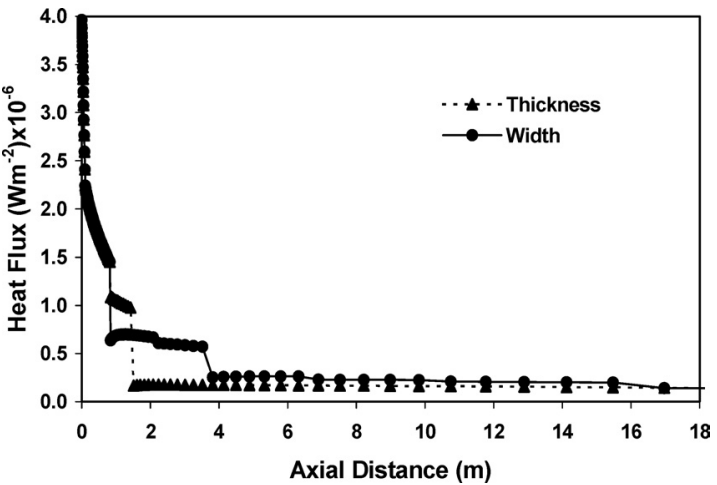

Fig. 8. Variation of slab surface heat flux along axial distance at the center of the surfaces at casting speed $1.6 \mathrm{~m} / \mathrm{min}$.

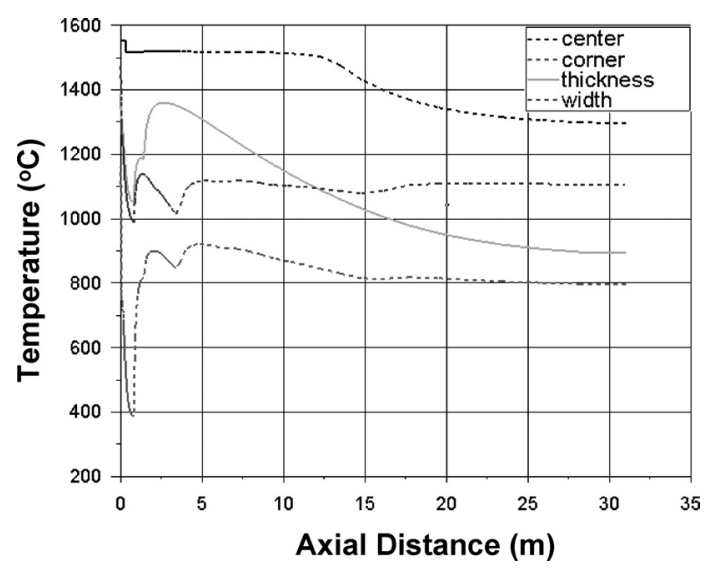

Fig. 9. Temperature profile for the casting speed $1.0 \mathrm{~m} / \mathrm{min}$.

wide side surface temperature. There is sharp decrease of temperature in the mould region. After the mould region, the temperature first increases in the spray ring cooling zone (zone 0 ). The reheat temperature is approximately $140^{\circ} \mathrm{C}$. This trend is continued to some distance in zone $1 \mathrm{~A}$ because of same heat transfer coefficient. The surface of slab attains a peak temperature. Thereafter temperature decreases. The decrease of temperature is continued in zone $1 \mathrm{~B}$. In zone 2 , the surface temperature increases because of reduce heat transfer coefficient. The increase of temperature is approximately $100^{\circ} \mathrm{C}$. In the zone 3,4 and 5 the surface temperature reduces very less because of low cooling. After zone 5, there is slight increase of temperature, because the spray cooling is stopped and slab is allowed to be radiant cooled. The solid line curve (thickness) is for slab middle narrow side surface temperature. Like the width curve, there is sharp decreases of temperature in this surface in the mould region. However, because of superheated liquid jet impinging the surface, heating of solidified shell takes place in the mould and thus this temperature is higher than the width temperature. The temperature then rises because of reduce cooling in zone $0 \mathrm{~N} \& \mathrm{~S}$. The reheat temperature is $160^{\circ} \mathrm{C}$. The surface temperature then stabilizes at some temperature in this zone. The surface temperature again increases after this zone because the spray cooling is stopped. The surface reheat is $180^{\circ} \mathrm{C}$. It attains a maximum temperature for the same reason as stated above and thereafter temperature decreases because of radiation cooling. This temperature goes below the upper curve at around $12.0 \mathrm{~m}$.

The measured temperature by radiation pyrometer at a 


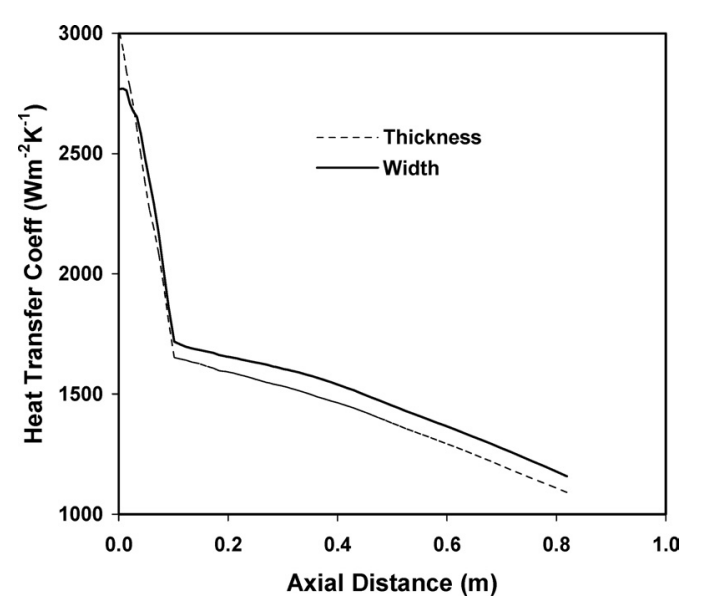

Fig. 10. Variation of slab surface heat transfer coefficient in the mould region along axial distance at the center of the surfaces at casting speed $1.0 \mathrm{~m} / \mathrm{min}$.

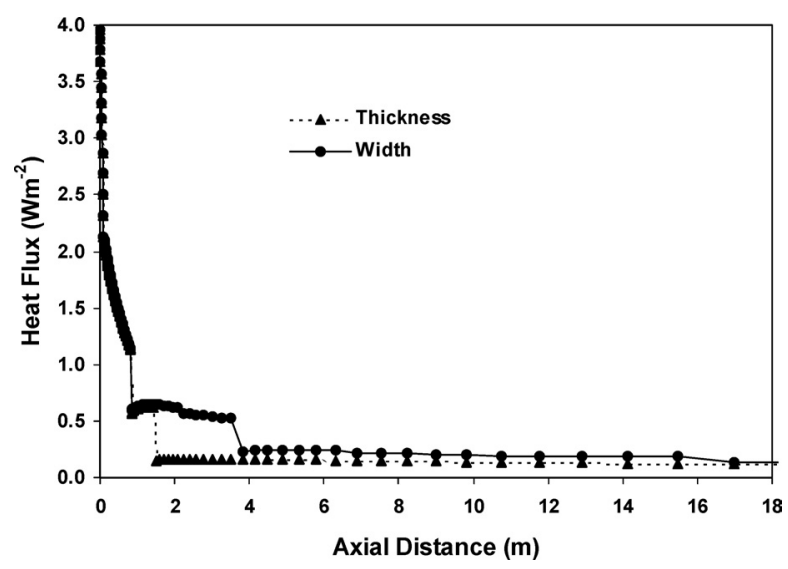

Fig. 11. Variation of slab surface heat flux along axial distance at the center of the surfaces at casting speed $1.0 \mathrm{~m} / \mathrm{min}$.

distance $10 \mathrm{~m}$ from the meniscus at thickness direction is in the range of 735 to $1100^{\circ} \mathrm{C}$, which is below the predicted temperature for the same reason as stated in Fig. 5. The corner temperature is less because of two dimensional cooling.

Figure 10 shows the computationally obtained slab surface heat transfer coefficient in the mould at casting speed $1.0 \mathrm{~m} / \mathrm{min}$. Because of less speed, the heat transfer coefficient of the narrow and wide faces do not differ much. At the exit of the mould, in the narrow face (thickness) heat transfer coefficient is $1100 \mathrm{~W} \mathrm{~m}^{-2} \mathrm{~K}^{-1}$, while in the wide face (width) its value is $1150 \mathrm{~W} \mathrm{~m}^{-2} \mathrm{~K}^{-1}$. In the zone 0 , the heat transfer coefficient is $412 \mathrm{~W} \mathrm{~m}^{-2} \mathrm{~K}^{-1}$ and in the zone 0 $(\mathrm{N} \& \mathrm{~S})$, its value is $532 \mathrm{~W} \mathrm{~m}^{-2} \mathrm{~K}^{-1}$. Both the values are much lower than the calculated heat transfer coefficient at the exit of the mould.

Figure 11 shows the change of heat flux along the axial distance from the meniscus at the center of the surfaces at casting speed $1.0 \mathrm{~m} / \mathrm{min}$. For the sake of comparison, the heat flux value of the mould also has been included. Figure clearly shows the abrupt change of heat flux.

Figure 12 shows the temperature profile at the central plane along axial distance at casting speed $0.6 \mathrm{~m} / \mathrm{min}$. In this figure, upper curve (center) is for the slab center temperature. This temperature decreases slowly till solidification. The curve (width) which is near the solid line is for slab middle wide side surface temperature. There is sharp decrease of temperature in the mould region. After the

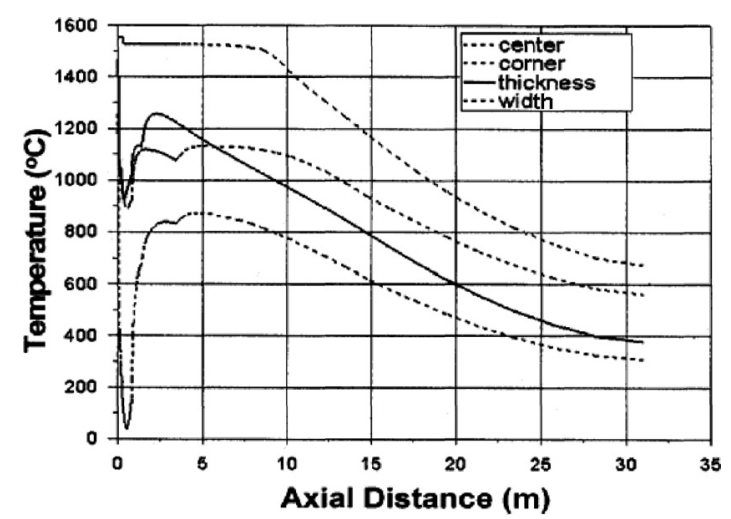

Fig. 12. Temperature profile for the casting speed $0.6 \mathrm{~m} / \mathrm{min}$.

mould region, the temperature first increases in the spray ring cooling zone (zone 0 ). The reheat temperature is approximately $120^{\circ} \mathrm{C}$. This trend is continued to some distance in zone 1A because of same heat transfer coefficient. This surface of slab attains a peak temperature. Thereafter temperature decreases. The decrease of temperature is continued in zone $1 \mathrm{~B}$. In zone 2 , the surface temperature increases, because of reduce heat transfer coefficient. The increase of temperature is approximately $40^{\circ} \mathrm{C}$. In the zone 3 , 4 and 5 the surface temperature reduces very less because of low cooling. After zone 5, there is no increase of temperature, even though the spray cooling is stopped and slab is allowed to be radiant cooled. The solid line curve (thickness) is for slab middle narrow side surface temperature. Like the width curve, there is sharp decrease of temperature in this surface in the mould region. However, because of superheated liquid jet impinging the surface, heating of solidified shell takes place in the mould and thus this temperature is higher than the width temperature. The temperature then rises because of reduce cooling in zone $0 \mathrm{~N} \& \mathrm{~S}$. The reheat temperature is $220^{\circ} \mathrm{C}$. The surface temperature then stabilizes at some temperature in this zone. The surface temperature increases after this zone because the spray cooling is stopped. The surface reheat is $160^{\circ} \mathrm{C}$. It attains a maximum temperature for the same reason as stated above and thereafter temperature decreases because of radiation cooling. This temperature goes below the upper curve at around $6.0 \mathrm{~m}$, because there is thick shell at this point and thus there is not much heat flux from the center.

The measured temperature by radiation pyrometer at a distance $10 \mathrm{~m}$ from the meniscus at thickness direction is in the range of 700 to $900^{\circ} \mathrm{C}$, which is below the predicted temperature for the same reason as stated in Fig. 5 and Fig. 9. The corner temperature is less because of two dimensional cooling. Overall temperature is lower than casting speed $1.6 \mathrm{~m} / \mathrm{min}$ and $1.0 \mathrm{~m} / \mathrm{min}$ because of more residence time of slab in the mould. The wide face temperature goes lower than the austenite-ferrite temperature in the mould. In order to avoid the lowering of temperature below austenite ferrite temperature, since spray cooling is already low, it is recommended to reduce the liquid height in the mould at low speed.

Figure 13 shows the computationally obtained slab surface heat transfer coefficient in the mould at casting speed $0.6 \mathrm{~m} / \mathrm{min}$. Because of less casting speed, the heat transfer coefficient of the narrow and wide faces do not differ much. In both the faces, heat transfer coefficient is around $700 \mathrm{~W} \mathrm{~m}^{-2} \mathrm{~K}^{-1}$. In the zone 0 , heat transfer coefficient is 


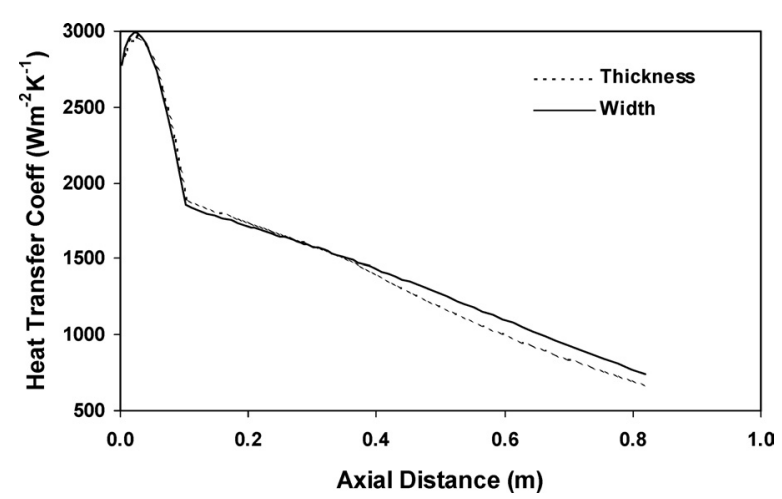

Fig. 13. Variation of slab surface heat transfer coefficient in the mould region along axial distance at the center of the surfaces at casting speed $0.6 \mathrm{~m} / \mathrm{min}$.

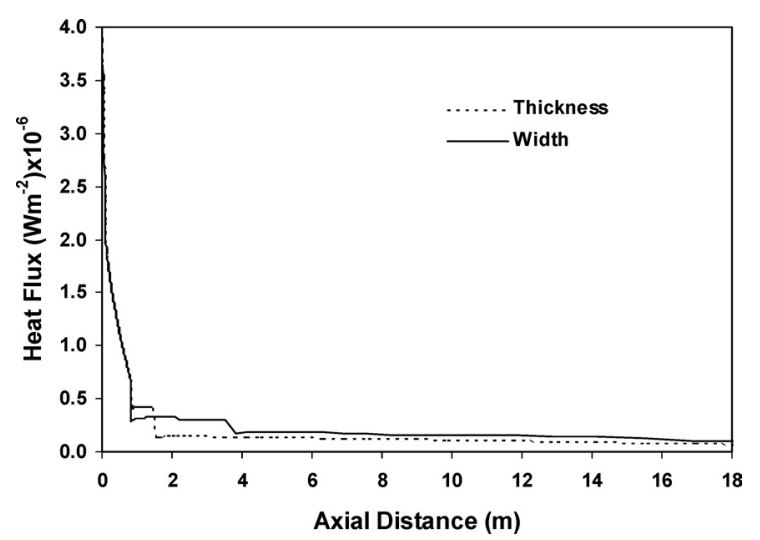

Fig. 14. Variation of slab surface heat flux along axial distance at the center of the surfaces at casting speed $0.6 \mathrm{~m} / \mathrm{min}$.

$300 \mathrm{~W} \mathrm{~m}^{-2} \mathrm{~K}^{-1}$, while in the zone $0(\mathrm{~N} \& \mathrm{~S})$, its value is $392 \mathrm{~W} \mathrm{~m}^{-2} \mathrm{~K}^{-1}$.

Figure 14 shows the change of heat flux along the axial distance from the meniscus at the center of the surfaces at casting speed $0.6 \mathrm{~m} / \mathrm{min}$. For the sake of comparison, the heat flux value of the mould also has been included. Figure clearly shows the abrupt change of heat flux.

\section{Conclusions}

(1) Three dimensional mathematical model based on turbulent fluid flow including SEN, heat transfer and solidification considerations has been developed to predict the slab surface temperature, shell thickness, heat transfer coefficient and heat flux.

(2) For low carbon steel, the mould heat flux calculated by Savage and Prichard expression and measured in the continuous caster of Tata Steel slab A are in the same range.

(3) The predicted and the measured surface temperatures at $10.0 \mathrm{~m}$ from the meniscus are within the error limit. Therefore, the assumption that the surface temperature of slab in the spray cooling zone is above the Leidenfrost temperature is valid for the present situation.

(4) Austenite-ferrite transformation for low carbon steel is accompanied by large volume variation, which may lead to stress and crack. The predicted slab surface temperature was not always above the austenite-ferrite transformation temperature.

(5) Because of complex nature of atmoshphere inside the spray cooling chamber, it is difficult to measure the temperature of the slab accurately. Most of the scale forms at the narrow side of the caster. The pyrometer is situated at the narrow side of the slab.

(6) Calculation of heat transfer coefficient shows that there are sudden changes of its value between mould exitspray ring. It is recommended to change the water and air flow rate of the spray such that the maximum surface reheat should be below $50^{\circ} \mathrm{C}$.

(7) For the casting speed lower than $1.0 \mathrm{~m} / \mathrm{min}$, complete solidification of slab takes place at distance below $13.0 \mathrm{~m}$. It is recommended to lower the liquid metal height in the mould for these speeds to increase the metallurgical length which will reduce the thermal stresses.

(8) Because slab attains temperature lower than the austenite-ferrite temperature in the mould for low speed, it is recommended to lower the liquid metal height in the mould in these cases to increase its temperature.

\section{Acknowledgement}

The authors would like to thank the management of Tata Steel, India, for giving permission to publish this work.

\section{Nomenclature}

$A_{\text {mush }}$ : Mushy zone constant $\left(10^{5}\right)$

$C_{1}, C_{2}, C_{\mu}:$ Turbulent constant

$g$ : Acceleration due to gravity $\left(9.81 \mathrm{~m} \mathrm{~s}^{-2}\right)$

$G_{k}$ : Generation of turbulent kinetic energy $\left(\mathrm{kg} \mathrm{m}^{-1} \mathrm{~s}^{-3}\right)$

$H$ : Total enthalpy of the material $\left(\mathrm{J} \mathrm{kg}^{-1}\right)$

$h$ : Sensible enthalpy $\left(\mathrm{J} \mathrm{kg}^{-1}\right)$

$h_{\mathrm{s}}$ : Spray heat transfer coefficient $\left(\mathrm{W} \mathrm{m}^{-2} \mathrm{~K}^{-1}\right)$

$\Delta H:$ Latent heat content $\left(\mathrm{J} \mathrm{kg}^{-1}\right)$

$\Delta H_{\mathrm{f}}$ : Latent heat of the material $\left(\mathrm{J} \mathrm{kg}^{-1}\right)$

$k$ : Turbulent kinetic energy $\left(\mathrm{m}^{2} \mathrm{~s}^{-2}\right)$

$k_{1}$ : Laminar thermal conductivity $\left(\mathrm{W} \mathrm{m}^{-2} \mathrm{~K}^{-1}\right)$

$k_{\mathrm{t}}$ : Turbulent thermal conductivity $\left(\mathrm{W} \mathrm{m}^{-2} \mathrm{~K}^{-1}\right)$

$k_{\text {eff }}$ : Effective thermal conductivity $\left(\mathrm{W} \mathrm{m}^{-2} \mathrm{~K}^{-1}\right)$

$p$ : Pressure $\left(\mathrm{kg} \mathrm{m}^{-1} \mathrm{~s}^{-2}\right)$

$\mathrm{Pr}_{\mathrm{t}}$ : Turbulent Prandtl number $(-)$

$q_{\mathrm{m}}$ : Mould heat flux $\left(\mathrm{W} \mathrm{m}^{-2}\right)$

$q_{\mathrm{s}}$ : Surface heat flux $\left(\mathrm{W} \mathrm{m}^{-2}\right)$

$S: \quad$ Strain rate $\left(\mathrm{s}^{-1}\right)$

$T: \quad$ Slab temperature $\left({ }^{\circ} \mathrm{C}\right)$

$T_{\mathrm{s}}:$ Surface temperature $\left({ }^{\circ} \mathrm{C}\right)$

$T_{\mathrm{a}}$ : Air temperature $\left({ }^{\circ} \mathrm{C}\right)$

$T_{\text {solidus }}$ : Solidus temperature $\left({ }^{\circ} \mathrm{C}\right)$

$T_{\text {liquidus }}:$ Liquidus temperature $\left({ }^{\circ} \mathrm{C}\right)$

$u_{x}: x$-direction velocity $\left(\mathrm{m} \mathrm{s}^{-1}\right)$

$u_{y}$ : Casting-direction velocity $\left(\mathrm{m} \mathrm{s}^{-1}\right)$

$u_{z}: \quad z$-direction velocity $\left(\mathrm{m} \mathrm{s}^{-1}\right)$

$U$ : Casting speed $\left(\mathrm{m} \mathrm{s}^{-1}\right)$

$U_{\text {in }}$ : Liquid inlet velocity $\left(\mathrm{m} \mathrm{s}^{-1}\right)$

$x$ : Coordinate along width direction

$z$ : Coordinate along thickness direction

$y$ : Coordinate along casting direction

$\beta$ : Volume liquid fraction $(-)$

$\rho$ : Density of solid and liquid $\left(\mathrm{kg} \mathrm{m}^{-3}\right)$

$\beta$ : Volume liquid fraction $(-)$

$\sigma$ : Stefan constant $\left(5.6696 \times 10^{-8} \mathrm{~W} \mathrm{~m}^{-2} \mathrm{~K}^{-4}\right)$

$\sigma_{k}$ : Turbulent Prandtl number for $k(-)$

$\sigma_{\varepsilon}$ : Turbulent Prandtl number for $\varepsilon(-)$

$\varepsilon$ : Energy dissipation rate $\left(\mathrm{m}^{2} \mathrm{~s}^{-3}\right)$ 
$\varepsilon_{\mathrm{s}}: \quad$ Surface emissivity $(0.8)$

$\mu_{1}$ : Laminar viscosity $\left(\mathrm{kg} \mathrm{m}^{-1} \mathrm{~s}^{-1}\right)$

$\mu_{\mathrm{t}}$ : Turbulent viscosity $\left(\mathrm{kg} \mathrm{m}^{-1} \mathrm{~s}^{-1}\right)$

$\mu_{\mathrm{e}}$ : Effective viscosity $\left(\mathrm{kg} \mathrm{m}^{-1} \mathrm{~s}^{-1}\right)$

$v$ : Kinematic viscosity $\left(\mathrm{m} \mathrm{s}^{-2}\right)$

$\eta$ : Dimensionless mean strain rate $(-)$

\section{REFERENCES}

1) R. G. Rao and T. Kumar: Tata Search, (1995), 73.

2) S. Chandra: Quantitative Approaches in Process Metallurgy, 1st ed., ed. by A. K. Tripathy, P. Dutta and H. S. Ray, Allied Publishers, (1995), 377.

3) S. Chandra: Ph. D Thesis, Dept. of Metals \& Materials Engg., University of British Columbia, Canada, (1992).

4) I. V. Samarasekera, D. L. Anderson and J. K. Brimacombe: Metall. Trans. B, 13B (1982), March, 91.

5) I. V. Samarasekera and J. K. Brimacombe: W. O. Philbrook Memorial Symp. Conf. Proc., ISS-AIME, Warrendale, PA, (1988), 157.

6) B. G. Thomas: Continuous Casting: Modeling, The Encyclopedia of Advanced Materials, Vol. 2, ed. by J. Dantzig, A. Greenwell and J. Michalczyk, Pergamon Elsevier Science Ltd., Oxford, UK, (2001), 1595.

7) S. N. Singh and K. E. Blazek: Open Hearth Proc. AIME, New York, (1976), 264.

8) J. Savage and W. H. Prichard: J. Iron Steel Inst., 178 (1954), Nov., 269.

9) I. V. Samarasekra and J. K. Brimacombe: Metall. Trans. B, 13B (1982), 105.

10) A. Chatterjee, P. K. Mukhopadhaya, R. Dutta, J. K. Saha and S. Chandra: Tata Search, (1994), 92.

11) J. K. Brimacombe, J. E. Lait and F. Weinberg: Proc. of the Second ISI Conf. on Mathematical Process Models Applied in Iron and Steelmaking, Met. Soc., London, (1975), 174.

12) E. A. Mizikar: Trans. Metall. Soc. AIME, 239 (1967), 1747.

13) D. Mazumdar: ISIJ Int., 29 (1989), 524.

14) D. Mazumdar and R. Verma: Trans. Indian Inst. Met., 42 (1989), 447.

15) S. Govindarajan, R. Dutta and A. Chatterjee: Proc. of the Sixth Int. Iron and Steel Cong., Vol. 3, ISIJ, Tokyo, (1990), 197

16) J. K. Brimacombe: Can. Metall. Q., 15 (1976), 2, 17.

17) A. Perkins and W. R. Irving: Proc. of Conf. on Mathematical Process Models Applied in Iron and Steelmaking, ISI, Amsterdam, (1973), 187.

18) B. Lally, L. Biegler and H. Henien: Metall. Trans. B, (1990), 761.

19) S. K. Choudhary, D. Mazumdar and A. Ghosh: ISIJ Int., 33 (1993), 764.

20) A. K. Lahiri: Proc. Conf. Int. Symp. on Continuous Casting, Indian Inst. Met., Calcutta, (1989), 145.

21) T. S. P. Kumar: Tata Search, (1996), 83.

22) H. Wang, G. Li, Y. Lei, Y. Zhao, Q. Dai and J. Wang: ISIJ Int., 45 (2005), 1291

23) S. Louhenkilpi, J. Miettinen and L. Holappa: ISIJ Int., 46 (2006), 914.

24) R. Dautov, R. Kadyrov, E. Laitinen, A. Lapin, J. Pieska and V. Toivoren: Lobachevskii J. Math., 13 (2003), 3.

25) J. Szekely and R. T. Yadoya: Proc. of Conf. on Mathematical Process Models Applied in Iron and Steelmaking, ISI, Amsterdam, (1973), 165.

26) S. K. Choudhary and D. Mazumdar: ISIJ Int., 34 (1994), 584.
27) M. B. Goldschmit: Steelmaking Conference Proc., ISS, Warrendale, PA, (1997), 337.

28) X. Huang, B. G. Thomas and F. M. Najjar: Metall. Trans. B, 23B (1992), 339

29) B. G. Thomas, A. Denissov and H. Bai: Steelmaking Conf. Proc., ISS, Warrendale, PA, (1997), 375.

30) P. J. Flint, Q. L. He, R. B. Mahapatra and J. Herbertson: 10th PTD Conf. Proc., ISS, Warrendale, PA, (1992), 279.

31) R. C. Sussman and M. T. Burns: 10th PTD Conf. Proc., ISS, Warrendale, PA, (1992), 291.

32) S. Qiu, H. Liu, S. Peng and Y. Gan: ISIJ Int., 44 (2004), 1376.

33) X. Huang and B. G. Thomas: Can. Metall. Q., 37 (1998), No. 3-4, 197.

34) S. H. Seyedein and M. Hasan: Can. Metall. Q., 37 (1998), No. 3-4, 213.

35) B. E. Launder and B. I. Sharma: Lett. Heat Mass Transfer, (1974), No. 1, 131.

36) P. J. Flint: Steelmaking Conf. Proc., ISS, Warrendale, PA, (1990), 481.

37) Q. Yuan, B. G. Thomas and S. P. Vanka: Metall. Mater. Trans. B, 35B (2004), 685.

38) Q. Yuan, S. Sivaramakrishnan, S. P. Vanka and B. G. Thomas: Metall. Mater. Trans. B, 35B (2004), 967.

39) P. Ramirez-Lopez, R. D. Morales, R. Sanchez-Perez, L. G. Demedices and O. Davila: Metall. Mater. Trans. B, 36B (2005), 787.

40) R. Miranda, M. A. Barron, J. Barreto, L. Hoyos and J. Gonzalez: ISIJ Int., 45 (2005), 1626.

41) H. Yang, L. Zhao, X. Zhang, K. Deng, W. Li and Y. Gan: Metall. Mater. Trans. B, 29B (1998), 1345.

42) K. Takatani, Y. Tanizawa, H. Mizukami and K. Nishimura: ISIJ Int., 41 (2001), 1252.

43) K. Takatani: ISIJ Int., 43 (2003), 915.

44) E. A. Mizikar: Iron Steel Eng., 47 (1970), 53.

45) P. K. Agarwal, R. W. Pugh and J. K. Brimacombe: ISS Transactions, 3 (1983), 36.

46) A. Chatterjee, B. Basu, P. K. Mukhopadhaya and R. Dutta: Tata Search, (1996), 68.

47) M. R. Aboutalebi, M. Hasan and R. I. L. Guthrie: Metall. Mater. Trans., 26B (1995), 731.

48) R. B. Bird, W. E. Stewart and E. W. Lightfoot, Transport Phenomena, Wiley International Edition, New York, NY, (1960).

49) T. H. Shih, W. W. Liou, A. Shabbir, Z. Yang and J. Zhu: Computers Fluids, 24 (1995), 227.

50) B. Kader: Int. J. Heat Mass Transfer, 24 (1981), 1541.

51) J. K. Brimacombe, P. K. Agarwal, S. Hibbins, B. Prabhakar and L. A. Baptisa: Continuous Casting, Vol. II, ISS-AIME, Warrendale, PA, (1984), 109.

52) G. Kaestle, H. Jacobi and K. Wunnenburg: 65th Steelmaking Conf., ISS-AIME, Pittsburgh, (1982), 251.

53) P. Benoit and Ph. Pithois: Proc. Int. Conf. on Continuous Casting of Steel, The Metals Society IRSID, Biarritz, France, (1976), 92.

54) M. Raudensky and J. Horsky: Ironmaking Steelmaking, 32 (2005), 159.

55) S. V. Patankar: Numerical Heat Transfer and Fluid Flow, Hemisphere, New York, NY, (1980).

56) V. R. Voller and C. Prakash: Int. J. Heat Mass Transfer, 30 (1987), 1709.

57) J. E. Lait, J. K. Brimacombe and F. Weinberg, Ironmaking Steelmaking, 2 (1974), 90.

58) J. K. Brimacombe and F. Weinberg: J. Iron Steel Inst., 211 (1973), 24 